\title{
The Molecular Evidence of Babesia microti in Hard Ticks Removed from Dogs in Warsaw (central Poland)
}

\author{
WOJCIECH ZYGNER ${ }^{1 *}$, PIOTR BĄSKA ${ }^{1}$, MARCIN WIŚNIEWSKI ${ }^{1}$ and HALINA WĘDRYCHOWICZ ${ }^{1,2}$ \\ ${ }^{1}$ Division of Parasitology and Parasitic Diseases, Department of Preclinical Sciences, \\ Faculty of Veterinary Medicine, Warsaw University of Life Sciences, Warsaw, Poland \\ ${ }^{2}$ Laboratory of Molecular Parasitology, W. Stefański Institute of Parasitology, \\ Polish Academy of Sciences, Warsaw, Poland
}

Received 12 December 2009, revised 7 February 2010, accepted 15 February 2010

\author{
Abstract
}

\begin{abstract}
The purpose of this study was to specify the occurrence and prevalence of Babesia microti in hard ticks removed from dogs in Warsaw (central Poland). Among 590 collected ticks, 209 were identified as Ixodes ricinus, and 381 as Dermacentor reticulatus. B. microti DNA was detected in 11 out of $590(1.86 \%)$ samples of ticks. The DNA of the parasite was detected only in lysates from female $I$. ricinus ticks (11 out of $193 ; 5.7 \%)$. The result of this study is the first evidence of B. microti in I. ricinus ticks in Warsaw.
\end{abstract}

K e y w ords: Babesia microti, Ixodes ricinus, human babesiosis, Poland

\section{Introduction}

Among hard ticks, Ixodes ricinus is the most common tick occurring in Poland. The parasite plays an important role as a vector and reservoir of many viral, bacterial and protozoan pathogens (Siuda, 1993). One of these pathogens is Babesia microti, a protozoan parasite responsible for human babesiosis. Although I. ricinus is considered the final host of B. microti, one of the most recent studies from Poland showed that the tick Dermacentor reticulatus can also be infected with this parasite (Welc-Falęciak et al., 2008). The disease caused by B. microti occurs mainly in North America where the parasite is transmitted by I. scapularis (formerly I. dammini). Although B. microti was detected in ticks and rodents in Europe, $B$. divergens and $B$. venatorum are considered as the main cause of human babesiosis on this continent (Brasseur and Gorenflot, 1996; Herwaldt et al., 2003; Homer et al., 2000; Šebek et al., 1977). In Poland human babesiosis caused by $B$. microti was described only in one case, but the infection was imported from Brazil (Humiczewska and Kuźna-Grygiel, 1997). These literature data seem to suggest that in Europe human babesiosis is caused only by $B$. divergens and B. venatorum. However, Hildebrandt et al. (2007) confirmed the first autochthonous case of human B. microti infection in Europe. The result of that study suggests that there is a risk of $B$. microti infection in humans in Europe. Thus, B. microti detected in rodents and ticks in Poland can be also infective for humans. Many studies from our country showed that B. microti occurs (in ticks and rodents) in northern, south-western and eastern Poland (Karbowiak et al., 1999; Pawełczyk et al., 2004; Siński et al., 2006; Skotarczak et al., 2002; Skotarczak and Cichocka, 2001; Skotarczak and Sawczuk, 2003; Stańczak et al., 2004; Welc-Falęciak et al., 2008; Wójcik-Fatla et al., 2009). However, to the best knowledge of the authors of this study, there is no any study on the occurrence of B. microti in central Poland.

The aim of this study is to continue the previous surveys (Zygner and Wędrychowicz, 2006; Zygner et al., 2008). In those works two species of ticks in dogs from Warsaw were detected. Among all collected ticks $35.4 \%$ were identified as I. ricinus and $64.6 \%$ as D. reticulatus. PCR revealed that $11 \%$ of $D$. reticulatus ticks harboured DNA of Babesia canis, $6.2 \%$ of

\footnotetext{
* Corresponding author: W. Zygner, Division of Parasitology and Parasitic Diseases, Department of Preclinical Sciences, Faculty of Veterinary Medicine, Warsaw University of Life Sciences - SGGW, Ciszewskiego 8, 02-786 Warsaw, Poland; phone: (+48) 22 593 6045 ; fax: (+48) 2259360 48; e-mail: wojciechzygner@yahoo.pl
} 
I. ricinus harboured Borrelia afzelii, and DNA of Anaplasma phagocytophilum was detected in $2.9 \%$ of $I$. ricinus ticks. In the presented study the authors estimated the prevalence of B. microti infection in ticks collected form dogs in Warsaw.

\section{Experimental}

\section{Materials and Methods}

Tick sampling. During 2 years, from March 2003 to February 2005, ticks were collected in Warsaw veterinary clinics from dogs presented for veterinary care. Among 590 collected ticks, 381 were identified as D. reticulatus, and among them, 137 as male and 244 as female specimens. The other 209 out of 590 ticks were identified as I. ricinus, and among them, 16 specimens were males and 193 were females. Larval or nymphal stages of ticks were not found in these dogs (Zygner and Wędrychowicz, 2006). All collected ticks were attached to the skin of the examined dogs except 16 collected I. ricinus male specimens. All D. reticulatus ticks and most of I. ricinus female ticks (171) were engorged or partly engorged. Only 22 collected $I$. ricinus female and all I. ricinus male ticks were no engorged.

DNA extraction. All collected ticks were kept at $-70^{\circ} \mathrm{C}\left(\right.$ Jouan $^{\circledR}$ VX 530 Series 2) until the isolation of DNA was performed. Before DNA extraction ticks were washed in $70 \%$ ethanol and sterile water, they were then homogenized in $100 \mathrm{ml}$ PBS with sterile pestle. DNA was extracted from individual ticks using the Genomic Mini kit (A\&A Biotechnology) according to the manufacturer's instructions, preceded by $6 \mathrm{~h}$ digestion with Proteinase $\mathrm{K}$. The efficiency of DNA isolation was confirmed by electrophoresis in a $1.5 \%$ agarose gel. Isolated DNA was stored at $-70^{\circ} \mathrm{C}$.

Amplification of $B$. microti DNA. Lysates from ticks were used to detect DNA of B. microti. PCR was performed according to Persing et al. (1992) with the primers Bab-1 (5' CTT AGT ATA AGC TTT TAT ACA GC 3') and Bab-4 (5' ATA GGT CAG AAA CTT GAA TGA TAC A 3') used to amplify the $18 \mathrm{~S}$ rDNA gene fragment of $B$. microti. The expected product was about $238 \mathrm{bp}$ in size. As a positive control the authors used DNA lysate from the I. ricinus tick infected with B. microti. The infection in this specimen was confirmed by PCR and sequencing of the PCR product, which revealed to be $100 \%$ identical with a fragment of the B. microti $18 \mathrm{~S}$ ribosomal DNA gene under accession no. AY693840 in the GenBank ${ }^{\circledR}$ database. All PCRs were carried out in MJ Research PTC-200 thermal cycler. The size of the PCR product was analyzed by electrophoresis in a $1.5 \%$ agarose gel stained with ethidium bromide.
Sequencing of PCR products. The PCR products with the expected amplicon size were isolated from the agarose gel using the Gel-Out kit (A\&A Biotechnology). Next, all PCR products were sequenced to verify the presence of $B$. microti. The sequencing reaction was carried out on the AbiPrism ${ }^{\circledR}$ Genetic Analyser using computer program GeneScan ${ }^{\circledR}$ Analysis Software. The obtained sequences were compared to sequence data available in the GenBank ${ }^{\circledR}$ using the BLASTN 2.2.17 program (http://www.ncbi.nlm.nih. gov/BLAST/). New sequence was submitted to the GenBank $^{\circledR}$ database.

\section{Results}

B. microti DNA was detected in 11 out of 590 $(1.86 \%)$ samples of ticks. The DNA of the parasite was detected only in lysates from female $I$. ricinus ticks (11 out of $193 ; 5.7 \%$ ). Three out of 11 infected ticks were collected as partly engorged ticks and 8 out of them were collected as no engorged specimens. The 11 products were sequenced. The sequences showed $100 \%$ similarity with $18 \mathrm{~S}$ rDNA partial sequence of B. microti (accession no AY693840, Gray strain isolated from human). The sequence obtained in this study was submitted to the GenBank ${ }^{\circledR}$ database under accession no. EU882727.

\section{Discussion}

The result of this study is the first proof for the presence of B. microti in I. ricinus ticks in Warsaw. The prevalence of infected female $I$. ricinus ticks is similar to the results of previous studies from the Mazury Lakes District and Lublin macroregion (Siński et al., 2006; Wójcik-Fatla et al., 2009). In Mazury Lakes District $B$. microti DNA was detected in 4 out of $92(4.35 \%)$ collected female I. ricinus ticks. In the Lublin macroregion 25 out of 409 (6.11\%) female I. ricinus ticks harboured $B$. microti DNA. The highest prevalence of $B$. microti infection in female $I$. ricinus ticks was detected in north-western Poland, where $14.9-15.3 \%$ of female specimens were infected with this pathogen (Skotarczak and Cichocka, 2001; Skotarczak et al., 2002). However, in opposition to the mentioned works, in this study DNA of B. microti was detected only in female ticks. This result probably is the consequence of very small number of collected male ticks. The authors of this study did not detect B. microti DNA in D. reticulatus ticks. This result differs from the results of the previous study form north-eastern Poland (Welc-Falęciak et al., 2008) in which 2 out of 17 larvae and 16 out of 398 nymphs of $D$. reticulatus ticks were infected with $B$. microti. 
Detection of B. microti DNA in ticks collected from dogs shows that these ticks were probably infected as developmental stages like larva or nymph. This statement is based on the fact that the dog is not intermediate host of B. microti (Uilenberg, 2006) and 8 of infected ticks were collected as no engorged ticks. However, 3 out of infected specimens were collected as partly engorged and all these specimens were attached to the skin of dogs. It seems probable that the blood of dogs in the collected ticks was not the origin of $B$. microti DNA but this cannot be excluded.

Detection of B. microti DNA in Warsaw seems to suggest that there can be a risk of infection for humans. The question, does B. microti in Europe have any zoonotic potential seems to be still open. Although detection of B. microti DNA in ticks and rodents in many European countries, there was only one confirmed case of autochthonous human babesiosis in Europe. It seems important to mention that this first case of human B. microti infection in Europe was caused by a variant which showed $100 \%$ similarity with that zoonotic Gray strain (accession no AY693840). This fact shows that detected in Warsaw B. microti can have zoonotic potential as well.

\section{Literature}

Brasseur P. and A. Gorenflot. 1996. Human babesial infections in Europe. Rocz. Akad. Med. Bialymst. 41: 117-122.

Herwaldt B.L., S. Cacciò, F. Gherlinzoni, H. Aspöck, S.B. Slemenda, P. Piccaluga, G. Martinelli, R. Edelhofer, U. Hollenstein, G. Poletti and others. 2003. Molecular characterization of a non-Babesia divergens organism causing zoonotic babesiosis in Europe. Emerg. Infect. Dis. 9: 942-948.

Hildebrandt A., K.P. Hunfeld, M. Baier, A. Krumbholz, S. Sachse, T. Lorenzen, M. Kiehntopf, H.J. Fricke and E. Straube. 2007. First confirmed autochthonous case of human Babesia microti infection in Europe. Eur. J. Clin. Microbiol. Infect. Dis. 26: 595-601.

Homer M.J., I. Aguilar-Delfin, S.R. Telford III, P.J. Krause and D.H. Persing. 2000. Babesiosis. Clin. Microbiol. Rev. 13: 451-469.

Humiczewska M. and W. Kuźna-Grygiel. 1997. A case of imported human babesiosis in Poland (in Polish). Wiad. Parazytol. 43: 227-229.

Karbowiak G., M. Stanko, L. Rychlik, W. Nowakowski and K. Siuda. 1999. The new data about zoonotic reservoir of Babesia microti in small mammals in Poland. Acta Parasitol. 44: 142-144.
Pawelczyk A., A. Bajer, J.M. Behnke, F.S. Gilbert and E. Siński. 2004. Factors affecting the component community structure of haemoparasites in common voles (Microtus arvalis) from the Mazury Lake District region of Poland. Parasitol. Res. 92: 270-284.

Persing D.H., D. Mathiesen, W.F. Marshall, S.R. Telford, A. Spielman, J.W. Thomford and P.A. Conrad. 1992. Detection of Babesia microti by polymerase chain reaction. J. Clin. Microbiol. 30: 2097-2103.

Siński E., A. Bajer, R. Welc, A. Pawełczyk, M. Ogrzewalska and J.M. Behnke. 2006. Babesia microti: Prevalence in wild rodents and Ixodes ricinus ticks from the Mazury Lakes District of north-eastern Poland. Int. J. Med. Microbiol. 296 (Suppl 1): 137-143.

Siuda K. 1993. Ticks of Poland (Acari: Ixodida), Part II, Taxonomy and Distribution (in Polish). Polskie Towarzystwo Parazytologiczne, Warsaw.

Skotarczak B. and A. Cichocka. 2001. Isolation and amplification by polymerase chain reaction DNA of Babesia microti and Babesia divergens in ticks in Poland. Ann. Agric. Environ. Med. 8: $187-189$.

Skotarczak B. and M. Sawczuk. 2003. Occurrence of Babesia microti in ticks Ixodes ricinus on selected areas of western Pomerania (in Polish). Wiad. Parazytol. 49: 273-280.

Skotarczak B., B. Wodecka and A. Cichocka. 2002. Coexistence DNA of Borrelia burgdorferi sensu lato and Babesia microti in Ixodes ricinus ticks from north-western Poland. Ann. Agric. Environ. Med. 9: 25-28.

Stańczak J., R.M. Gabre, W. Kruminis-Lozowska, M. Racewicz and B. Kubica-Biernat. 2004. Ixodes ricinus as a vector of Borrelia burgdorferi sensu lato, Anaplasma phagocytophilum and Babesia microti in urban and suburban forests. Ann. Agric. Environ. Med. 11: 109-114.

Šebek Z., B. Rosický and W. Sixl. 1977. The occurrence of Babesiasis affecting small terrestrial mammals and the importance of this zoonosis in Europe. Folia Parasitol. 24: 221-228.

Uilenberg G. 2006. Babesia - A historical overview. Vet. Parasitol. 138: 3-10.

Welc-Falęciak R., A. Bajer, J.M. Behnke and E. Siński. 2008. Effects of host diversity and the community composition of hard ticks (Ixodidae) on Babesia microti infection. Int. J. Med. Microbiol. 298 (Suppl 1): 235-242.

Wójcik-Fatla A., J. Szymańska, L. Wdowiak, A. Buczek and J. Dutkiewicz. 2009. Coincidence of three pathogens (Borrelia burgdorferi sensu lato, Anaplasma phagocytophilum and Babesia microti) in Ixodes ricinus ticks in the Lublin macroregion. Ann. Agric. Environ. Med. 16: 151-158.

Zygner W., S. Jaros and H. Wędrychowicz. 2008. Prevalence of Babesia canis, Borrelia afzelii, and Anaplasma phagocytophilum infection in hard ticks removed from dogs in Warsaw (central Poland). Vet. Parasitol. 153: 139-142.

Zygner W. and H. Wędrychowicz. 2006. Occurrence of hard ticks in dogs from Warsaw area. Ann. Agric. Environ. Med. 13: 355-359. 